\title{
A case of sitosterolaemia with stomatocyticanaemia and thrombocytopenia treated with Ezetimibe with good response
}

\author{
Ching-ngar Hung ${ }^{1 *}$, Ching-yin Lee ${ }^{2}$ \\ From 7th APPES Biennial Scientific Meeting \\ Nusa Dua, Bali. 14-17 November 2012
}

Sitosterolaemia is a rare autosomal recessive lipid disorder characterized by increased absorption of plant sterols in the gut and decreased biliary excretion of sterols causing accumulation of plasma sterols, which can lead to premature atherosclerosis.

Here we reported a boy presented with multiple tuberous xanthomas at 4 year sold and was diagnosed sitosterolaemia [1]. The fasting plasma total cholesterol and low-density lipoprotein (LDL) cholesterol levels were 18.3 $\mathrm{mmol} / \mathrm{L}$ and $16.41 \mathrm{mmol} / \mathrm{L}$ respectively. Gas chromatography and mass spectrometry showed thatthefasting plasma sterols contained elevated beta-sitosterol $880 \mu \mathrm{mol} / \mathrm{L}$ (Reference range $<12 \mu \mathrm{mol} / \mathrm{L}$ ), campesterol $489 \mu \mathrm{mol} / \mathrm{L}$ (Reference range $<17.5 \mu \mathrm{mol} / \mathrm{L}$ ) and stigmasterol38.9 $\mu \mathrm{mol} / \mathrm{L}$ (Reference range $<3.5 \mu \mathrm{mol} / \mathrm{L}$ ). Molecular study identified compound heterozygous mutations (R419H and IVS12+IG $\rightarrow$ A)in the adenosine triphosphate (ATP) binding cassette subfamily $\mathrm{G}$, member 5 (ABCG5) gene.

Initial management included dietary restriction in cholesterol and plant sterols and cholestyraminetreatment.The total cholesterol and LDL cholesterol levels decreased.
The boy developed bleeding tendency with gum bleeding and epistaxis and hepatosplenomegalyat 7 years old. Blood test confirmed and thrombocytopenia and peripheralsmear revealed stomatocytichaemolyticanaemia and giant platelets [2]. Bone marrow study showed hypercellular marrow. He was treated with increasing dose of cholestyraminebut the drug compliance was fair. The haematological problems persisted.

At the age of 13,Ezetimibe 10mg daily was added. Ezetimibe blocks the absorption of dietary and biliary sources of cholesterol and plant sterols. The platelet count rose from $58 \times 10^{9} / \mathrm{L}$ to $107 \times 10^{9} / \mathrm{L}$ in 4 weeks' time and normalized after 10 months of Ezetimibe treatment. The haemoglobin level rose from $11 \mathrm{~g} / \mathrm{dL}$ to 13.8 $\mathrm{g} / \mathrm{dL}$ in 4 months. The plant sterol level also showed significant improvement (see table 1). There were decreased liver and spleen size. The drug was well tolerated with no adverse effect. The efficacy of Ezetimibe in our patient was sustained after 4 years of treatment which was consistent with the other studies on longterm Ezetimibe treatment [3-6].

Table 1

\begin{tabular}{|c|c|c|c|c|c|c|c|c|}
\hline & 2004 & 2006 & Mar 2008 & Jul 2008 (Ezetimide started in Jun 2008) & Nov 2008 & 2009 & 2010 & 2011 \\
\hline Haemoglobin (13-17 g/dL) & 8.8 & 8.9 & 11 & 10.5 & 13.8 & 14.6 & 14.4 & 15.7 \\
\hline Platelet $\left(150-400 \times 10^{9} / \mathrm{L}\right)$ & 60 & 59 & 58 & 107 & 100 & 167 & 262 & 124 \\
\hline Campesterol $(<17.5 \mu \mathrm{mol} / \mathrm{L})$ & 489 & 329 & 266 & - & - & 199 & 196 & 192 \\
\hline Stigmasterol $(<3 \mu \mathrm{mol} / \mathrm{L})$ & 38.9 & 31 & 19 & - & - & 22.3 & 24.8 & 27.6 \\
\hline $\begin{array}{l}\text { Beta-sitosterol }(<12 \mu \mathrm{mol} / \mathrm{L}) \\
\end{array}$ & 880 & 548 & 617 & - & - & 443 & 345 & 360 \\
\hline
\end{tabular}

'Department of Paediatrics and Adolescent Medicine, Princess Margaret

Hospital, Hong Kong, SAR

Full list of author information is available at the end of the article

(c) 2013 Hung and Lee; licensee BioMed Central Ltd. This is an Open Access article distributed under the terms of the Creative 
In conclusion, Ezetimibe treatment was effective in lowering the plasma cholesterol and sterols level in our patient with sitosterolaemia. It is also effective in reversing the stomatolyticanaemia and thrombocytopenia.

\section{Authors' details}

'Department of Paediatrics and Adolescent Medicine, Princess Margaret Hospital, Hong Kong, SAR. ${ }^{2}$ Department of Paediatrics and Adolescent Medicine, Caritas Medical Center, Hong Kong, SAR.

Published: 3 October 2013

\section{References}

1. Cheng WF, Yuen YP, et al: Sitosterolaemia and xanthomatosis in a child. Hong Kong Med J 2003, 9:206-209.

2. Rees DC, Iolascon A, et al: Stomatocytichaemolysis and macrothrombocytopenia (Mediterranean stomatocytosis/ macrothrombocytopenia) is the haematological presentation of phytosterolaemia. British Journal of Haematology 2005, 130:297-309.

3. Salen $\mathrm{G}$, von Bergmann $\mathrm{K}$, et al: Ezetimibe effectively reduces plasma plant sterols in patients with sitosterolemia. Circulation 2004, 109:966-971.

4. Salen $G$, Starc T, et al: Intestinal cholesterol absorption inhibitor Ezetimibe added to cholestyramine for sitosterolemia and xanthomatosis. Gastroenterology 2006, 130:1853-1857.

5. Lutjohann $\mathrm{D}$, von Bergmann $\mathrm{K}$, et al: Long-term efficacy and safety of ezetimibe $10 \mathrm{mg}$ in patients with homozygous sitosterolemia: a 2-year, open-label extension study. Int I ClinPract 2008, 62:1499-1510.

6. Niu DM, Chong KW, et al: Clinical observations, molecular genetic analysis, and treatment of sitosterolemia in infants and children. I Inherit Metab Dis 2010, 33:437-443.

doi:10.1186/1687-9856-2013-S1-P174

Cite this article as: Hung and Lee: A case of sitosterolaemia with stomatocyticanaemia and thrombocytopenia treated with Ezetimibe with good response. International Journal of Pediatric Endocrinology 2013 2013(Suppl 1):P174

\section{Submit your next manuscript to BioMed Central and take full advantage of:}

- Convenient online submission

- Thorough peer review

- No space constraints or color figure charges

- Immediate publication on acceptance

- Inclusion in PubMed, CAS, Scopus and Google Scholar

- Research which is freely available for redistribution

Submit your manuscript at www.biomedcentral.com/submit
Biomed Central 